\title{
Research on Two-Level Management Mode in Higher Vocational Schools
}

\author{
Chen Meixia ${ }^{1}$ \\ ${ }^{1}$ School of Public Management, Yunnan University of Finance \& Economics, China \\ yngcx@126.com
}

\begin{abstract}
In the paper the two-level management mode of higher vocational schools is studied based on such theories as new public management theory, vocational education and higher education management, the problems appearing in the reform on two-level management mode in higher vocational schools are analyzed with the combination of theory and practice. Based on that, it is proposed that it's necessary to sort out the relations among school management level, functional department and secondary college. Suggestions are given about the organizational framework, decision making and operating mechanism of two-level management in higher vocational schools.
\end{abstract}

Keywords: higher vocational school; two-level management; management mode

\section{Introduction}

Higher vocational education is another type and level of higher education in the national education system different from regular college education in that it is designed to cultivate practical technical talents based on vocational classification according to the actual business activity scope of certain vocational posts (groups). With more emphasis put on occupational pertinence and cultivation of occupational skills, such education is highly operable vocational skill education oriented with the market demand for social talents.

Internal management is the foundation for connotation construction of higher vocational schools and an important part of the core competitiveness.

Under the background where macro-policy has been gradually fully implemented, whether higher vocational schools can hold the opportunity for healthy development depends on the reform and innovation on internal management to a great extent. Therefore, higher vocational schools are required to have clear positioning and characteristics to get the space for survival and development in the field of higher education and vocational education. They are required to establish the talent cultivation mode different from regular colleges and secondary vocational schools; in particular, the exploration into higher vocational talent cultivation needs to get deep into secondary colleges and teaching/ research divisions. They need to establish and improve the two-level management system to clarify corresponding responsibility and authority of the school (department), thus to bring the role of different departments into full play in the process of exploring the talent cultivation mode.

\section{Present Situation of Two-Level Management Mode in Higher Vocational Schools}

\subsection{Analysis of internal management structure in higher vocational schools}

The organizational structure of internal management mode of a school, whether it is appraised by the Ministry of Education and the Ministry of Finance as one of the first 28 schools under the "national demonstration higher vocational school construction program or as other pillar schools of the country may be generally categorized into three groups: higher vocational school - school (department) - teaching/ research office (institute); higher vocational school - school - teaching/ research office (department or institute); and higher vocational school school- department (research center) - teaching/ research office. Schools of the first type have a large number of departments with specialized discipline, but the general size is small. Schools of the second type are usually large in size with the emphasis put on specialty group construction in integration of specialty and discipline resources, and the management is relatively centralized. And schools of the third type are generally strong in terms of professional skills and emphasize work division in terms of organizational structure. 


\subsection{Analysis of two-level management mode in higher vocational schools}

It is found in research that some national demonstration higher vocational schools of great strength apply the school - department two-level management mode. Based on that management mode, the level of school mainly plays the role of macro-management while the secondary college (department) is the entity of school running with the functions of teaching, research and social service. In terms of management and distribution system, the secondary college is highly independent; and in terms of fund allocation, the school allocates the fund separately and account independently according to the number of students, teaching workload, research fund and comprehensive evaluation, and each department may have different allocation scheme. In the process of management, the school mainly implements the target management mode centered on secondary colleges with relevant system established for standardized management.

With the upgrading of school running level and enlargement in size, some higher vocational schools are upgraded from technical secondary schools, some are the result of combination of several schools and some others are local higher vocational schools of clear positioning, so their target management modes are also different.

Therefore, the key to two-level management mode in higher vocational schools is the release of powers. To realize the effect of two-level management mode, power release must be reflected in all aspects including decision making, personnel, finance and academics.

\subsection{Two-level teaching management and research}

\section{management mode}

Under the two-level teaching management mode, the main teaching management department is the educational administration office which specifically manages the teaching work of the whole school under the direction of the president and competent vice president. The teaching management by department is mainly reflected in the decision making right in terms of student enrollment, discipline setting, talent cultivation and department adjustment, with the main content including implementing the decision made by the school on teaching management, organizing the formulation and implementation of various specialized teaching documents, organizing the teaching process and making overall arrangement for teaching work and teaching file management.

As higher vocational schools show the situation of coexistence of weakness and characteristics in terms of research, reform and innovation on research under the two-level management mode has become an important part of their internal management. Two-level research management refers to the relation mode between the school-level departments and secondary colleges in such sectors as application and implementation of research projects, research fund and conclusion appraisal. Teaching and research have formed close connection of a broad range and complicated relations.

Therefore, by establishing the two-level research management mode, higher vocational schools may make flexible use of school-business cooperation, fully integrate the resources of market and research, develop specialized and technical features through research and provide effective service for the society and economic development.

\section{Problems Existing in Two-Level Management Mode in Higher Vocational Schools}

Although higher vocational schools have gained many achievements in two-level management, the development of higher vocational schools has had adverse impact instead of bringing its positive role into play due to the failure to change the management ideas in time, unsound rules and regulations and supporting measures, singular supervision mechanism, unclear responsibility, authority, interest and work division and unreasonable setting of functional departments.

\subsection{Misunderstanding existing and inaccurate target positioning}

Many higher vocational schools have certain misunderstandings in the process of internal reform. On the one hand, they think that they may reduce management to relieve the affairs burden of the functional department by implementing the secondary college system, issuing relevant documents of two-level management and realizing release of management powers, thus to activate the enthusiasm of secondary college and improve the management performance. In specialized talent cultivation, however, they pin their hope on disciplinary advantages or featured specialties while ignoring balanced development. And on the other hand, the two-level management mode is still at the primary stage and it is bound to face the problems of theory improvement and relevant shortage of practical experience. In addition, as each school has different development history, goals and situations, there are no cases that can be learned from other schools. Therefore, the majority of higher vocational schools conduct management based on their own practical situation, so the phenomenon of inaccurate target positioning exists in the process of reform. 


\subsection{Unsound organizational framework and insufficient standardization}

Although some higher vocational schools have established the two-level management system and released corresponding management powers such as personnel, finance, teaching and research and student management, having implemented two-level management mode to some extent, they are still at the primary stage of two-level management in lack of a sound organizational framework. In particular, various working systems are not standardized enough and there are often no rules to follow in the process of management by the department. Besides, the administration personnel of the secondary college are not accustomed to the sudden change from management object to management subject, usually carrying out relevant work based on their personal experience and management ability, which leads to unclear responsibility, buckpassing of different posts and lower working efficiency.

\subsection{Insufficient executive force and obstructed}

\section{operational mechanism}

The operational mechanism of higher vocational schools refers to the way of interaction and interconnection among various elements within the system of a school as well as other social factors closely related to the operation of the school system. Such way of interaction and interconnection determines the structural characteristics of various components of the school system and determines the performance of their functions. Some higher vocational schools have established the two-level management mode pro forma, but they still follow the original management mode in practice with their management ideas hard to be integrated with the two-level management mode. They neither follow the rules of higher vocational education nor emphasize bringing the important role of academic powers into play in higher vocational schools. Therefore, two-level management usually cannot be continued, making the systematic work of establishing a system reduced to a wording game, finally making the secondary college unable to bear the responsibility for management.

\subsection{Unsound supervision mechanism with management}

risks

Supervision mechanism is the follow-up supervision of the matters to be supervised so as to further improve the executive force of the whole staff for the rules and regulations based on defining the work responsibility of each department. To further improve the working efficiency and optimizing the school running resources, higher vocational schools are also required to improve their rules and regulations and intensify supervision to improve the executive force of the management department of the secondary college. The establishment of two-level management mode enables the departments to get unprecedented powers, but the phenomenon of power abuse by the department and even out-of-control management if the responsibility is unclear with no relevant supervision and restricting mechanism, finally impeding the normal operation of school management. Therefore, while determining the degree of decentralization, they should establish suitable supervision mechanism for financial monitoring, teaching and research evaluation.

\section{Train of Thoughts for Reform and Innovation on}

\section{Two-Level Management Mode in Higher}

\section{Vocational Schools}

Looking into the future, the sustainable development of higher vocational schools relying on continuous reform and innovation will be an inevitable path for the development of higher vocational schools. Therefore, some suggestions are given based on some issues concerning the reform and innovation on the internal two-level management mode in higher vocational schools.

\subsection{Improving understanding and solidifying internal management objectives}

The innovative development of two-level management mode in higher vocational schools is consistent with the objectives of the educational management ideas and system. Hence, it is the foundation of internal two-level management to improve the perception level and change the management thoughts and ideas of the managers. To sum up, to make the goal of two-level management mode rooted in the minds of the school leaders and each of the staff and to realize the efficiency implementation is the key of implementation of the two-level management mode. So the internal management must be based on the goal of serving the grassroots teachers and all the students to satisfy their requirements for work and study, thus to sort out the responsibility - authority-interest relations of all levels and strengthen the foundation of internal management.

\section{2 .Setting up the organizational framework of}

\section{two-level management mode}

To realize the shift from bureaucratic management to professionalized management and improve the specialization of functional departments, it is to establish and improve the organizational structure led by specialization, bring the autonomy of departments into full 
play, change the role of departments and promote departments to emphasize teaching research, seek for market and seek for the opportunity of industry-teaching integration. Based on the rules of higher vocational education, it is to set up the new structure of higher vocational schools and reduce intermediate levels to further optimize the management organizational structure design. In a word, autonomy and independence is the fundamental requirement of two-level management mode. Only by mobilizing the activity, initiativeness and creativity of the departments may the development of higher vocational school adapt to the new challenges of the market economy system and improve the management efficiency and school running benefits.

\subsection{Smoothing the effective operating mechanism o}

\section{two-level management mode and strengthening the supervision and evaluation mechanism}

As a complicated organization both academic and administrative, higher vocational schools are characterized with duality internally, so it is inappropriate to operate totally led by administration or professor groups. In brief, school governance may not get the optimal effect by emphasizing any one group; instead, it is required to effectively coordinate administrative and academic powers to make the decision making more scientific. Administrative powers and academic powers are two kinds of powers of different meaning and nature with different operational way and value orientation. The former is institutionalized powers related to position, while the latter is the powers of academic management, mainly including management powers in terms of teaching activities, scientific research, discipline construction, curriculum setting, teaching material development, teacher training, degree granting and enrollment and employment. Therefore, administrative powers and academic powers should independent of each other.

\subsection{Establishing and strengthening competition mechanism for higher vocational schools}

Establishing and improving market competition mechanism may effectively promote higher vocational schools to improve quality and develop their respective features. Therefore, the features of higher vocational schools include features in terms of school running, management, education, teaching, discipline, specialty, curriculum, industrial development, regional development and talent cultivation. All those features require higher vocational schools be further integrated with market, strengthen the research on market and actively learn some management thoughts and ways from enterprises to optimize their management, improve the management efficiency and promote the high-efficiency operation of school running resources.

Only by releasing the power of resource management to the secondary college may the gap be shortened between managers and the market to enable them to quickly and accurately receive the demand information for technology and talents, make full use of their decision-making powers for teaching and research to establish their own features as well as the features of the school.

\section{Conclusion}

Considering that the internal management mode of domestic higher vocational schools is basically the management mode of ordinary colleges and universities, higher vocational schools take the way of "industry-school combination and school-business cooperation" with the school running tenet of cultivating production and service skill talents.

Higher vocational schools must innovate on the management mode to develop their own characteristics and brands. They must reform the original management mode with an opening attitude, change the traditional "pyramid" mode and establish a flat organizational structure to bring the subjective activity of the staff into full play and to improve the working efficiency. They should strengthen the organization construction on the decision making and execution levels to develop the standardized management procedures, improve the independence of secondary college, enhance the vitality of secondary college and intensify the sense of market and quality of the whole staff. They should also integrate the quality of students cultivated with the market demand and improve the talent cultivation quality evaluation system of higher vocational schools to make the "development of vocational education keep in pace with the times".

\section{References}

[1]. Website of the Central eople's Government of China: Li Keqiang, Vocational education reform must keep in pace with social development, 2014-03-01

[2]. Song Lina, Thoughts on several issues concerning reform on two-level management system in higher vocational schools from the perspective of target management, J. in Modern Vocational Education, 2013(4)

[3]. Zhao Ling, Moderate decentralization and vitality stimulation: reform on two-level management system in higher vocational schools, $\mathbf{J}$. in Vocational and Technical Education, 2012(32)

[4]. Deng Guoli, Setting principles and implementation strategies for secondary colleges of higher vocational school, J. in Journal of Shenzhen Institute of 
Information Technology, 2012(04)

[5]. Gao Fei, Shi Xinmin, Analysis of two-level management work in higher vocational schools, J. in Communication of Vocational Education, 2012(20)

[6]. Liu Qiong, Discussion on Management of Higher Vocational Schools, J. in Popular Business, 2010(04)

[7]. Yang Xi, Government shall release powers to colleges and universities in terms of discipline and specialty setting, N. in Guangming Daily, 2014-02-25 